\title{
At skrive til øret
}

\section{Betragtninger fra en Storytel Originals-forfatter}

"Hvordan er det egentlig at skrive til lyd? Er du nødt til at tænke på en helt anden måde? Og bliver det ikke meget underligt, hvis man læser en tekst, som er beregnet til at blive lyttet til?" Spørgsmål som disse har jeg ofte fået i de seneste år, efterhånden som den svenske bogbranche er begyndt at kredse mere og mere omkring lydbøger - og i takt med, at jeg selv, efter at have opnået en vis fremgang med Storytel Originals-serien Virus (2016-2018), er blevet en af forgrundsfigurerne inden for det at "skrive til øret."

Svarene er ikke særligt komplicerede. Den praktiske forskel mellem at skrive for henholdsvis lydbogsmarkedet og papirbogsmarkedet er ikke stor, og nej - jeg behøver ikke at tænke helt anderledes under skriveprocessen. Min erfaring er desuden, at man udmærket kan tilgå tekster, som først og fremmest er tiltænkt øret, selv gennem traditionel stillelæsning med øjnene. Men der findes selvfølgelig udfordringer. Lydbogsbrugerne går i nogen grad til litteraturen på en anden måde end papirsbogslæsere, og der findes faldgruber, jeg som lydbogsforfatter støder på, som en forfatter, der først og fremmest skriver til det trykte bogformat, ikke behøver at tænke på i samme omfang: Udfordringer, som for eksempel vedrører læsernes evne til at håndtere teknik, deres tålmodighed med teksten og koncentration i lyttesituationen, samt at jeg som forfatter overlader min tekst til en ekstern fortolker i form af en indlæsende skuespiller. En forfatter, som fokuserer på lydbogsmarkedet, stilles desuden over for udfordringer, som ligger hinsides selve skrivehåndværket: Lydbøger har eksisteret længe, men massemarkedet er ungt, og formatets anseelse inden for de mere litterære kredse er relativt lav, ligesom manglen på et fysisk produkt udelukker forfatteren fra flere vigtige sammenhænge i den litterære kultur. Vi, som skriver direkte til lydformatet, må forholde os til disse udfordringer og fors $\varnothing$ ge at finde veje rundt om dem.

I dette essay vil jeg komme nærmere ind på disse udfordringer og således beskrive, hvad det ud fra mine erfaringer vil sige at skrive til øret. Først er det imidlertid på sin plads med en baggrund for, hvordan jeg havnede i min nuværende position som lydbogsforfatter: Tidligt i januar 2016 blev jeg kontaktet af en redaktør på Storytel. De planlagde en egenproduktion af lydbøger under navnet Storytel Originals; tek- 
ster som inspireret af tv-serie-formatet skulle deles op i sæsoner og afsnit i stedet for at præsenteres som traditionelle bøger. Var jeg interesseret i at blive en del af dette? Satsningen blev tidligt mødt af kritik. Kontraktforholdene stak mange i øjnene: Til gengæld for et forskud, der lå højere end det, som er traditionen inden for branchen, krævede Storytel, at ophavs- og råderetten til alle formater og bearbejdninger skulle ligge hos dem. Særligt Forfatterforbundet i Sverige var kritiske; i et interview med branchetidsskriftet Svensk Bokhandel kaldte daværende forbundsordfører Gunnar Ardelius aftalen for "rigtig dårlig". Han mente, at ophavsretten er grundlæggende for en forfatters muligheder for at få en indkomst og kunne forsørge sig, og at Storytel med denne aftale i princippet vendte op og ned på den måde, ophavsretten fungerer på, og derved viste manglende forståelse for det litterære økosystem og for de værdier, som ophavspersonerne repræsenterer (Schmidt 2016).

Selv jeg var tvivlrådig. At miste ophavsretten til min egen fortælling og mine figurer virkede underligt, især da det ville indebære, at Storytel ville få ret til at lade en anden forfatter skrive videre på min serie, hvis jeg selv skulle blive træt af det. Men efter nogle dages overvejelser skrev jeg under. Jeg skal ikke lægge skjul på årsagen: det var pengene. Forskuddet, jeg fik for den første sæson af lydbogsserien Virus, var tre gange højere end det forskud, jeg havde fået fra det Bonnier-ejede forlag Forum for min debutroman Dannyboy \& kärleken et årti tidligere. Desuden skulle dette forskud udbetales, mens skrivearbejdet pågik, og ikke når manuskriptet var færdigt og indleveret, hvilket ellers er sædvanen i den svenske bogbranche.

Mit forfatterskab havde hidtil været bedrevet om aftenen og i weekender som en bibeskæftigelse ved siden af mit arbejde som kulturjournalist. Storytel Originalskontrakten gav mig en chance for at begynde at arbejde som forfatter på fuld tid for en tid. Det var en mulighed, jeg ville tage imod. Et halvt år senere blev den første sæson af min samtidsdystopi Virus en af de fire premiere-serier, som Storytel Originalskonceptet blev introduceret med, og med tiden blev serien den mest levedygtige af de fire med i alt syv sæsoner: først Virus sæson 1-4 og derefter efterfølgeren Smittad 1-3, hvor fortællingen flyttes frem i tid, og persongalleriet udvides. I sommeren 2019 udgav jeg også thrillerserien Nära gränsen, som blev Storytel Originals' første såkaldte 'juli-kalender': en sommerføljeton med et nyt afsnit hver dag i juli måned. En anden sæson af denne er nu fastsat til at udkomme tidligt i efteråret 2020.

Storytel Originals-serierne har ikke gjort mig rig. Men ved at holde et relativt højt skrivetempo og skrive to Original-sæsoner færdig per år, har jeg kunnet forsørge mig som forfatter i de seneste år. Hver ny sæson har dertil medført et øget antal lyttere til de ældre sæsoner, hvilket har betydet, at royalty-udbetalingerne kontinuerligt er steget. Alt $i$ alt har dette gjort mig til den forfatter, som har skrevet mest for Storytel Originals-satsningen i Sverige. En anden forfatter, som kontinuerligt har fået nye opgaver hos Storytel, er Jesper Ersgård, som først skrev science fiction-serien Svart stjärna (på dansk Sort stjerne) i tre sæsoner sammen med sin bror Joakim og derefter på egen hånd forfattede tidsrejseeventyret 1986 i snart tre sæsoner. Et tredje navn er Karin Jansson, som dels har skrevet den tre sæsoner lange feel goodserie Byvalla (på dansk Bykøbing), og som i efteråret 2019 publicerede første sæson af serien Kalla fötter (på dansk Kolde fødder). Jansson var også en af fire forfattere til Storytel Originals' julekalender i 2018, Centralgången. 
Der er således en voksende gruppe af forfattere i Sverige, men også i Danmark og internationalt, som arbejder og har succes med lydbogsformatet som deres primære format. ${ }^{I}$ Storytel Originals findes også som e-bøger, og visse serier er senere blevet udgivet i pocket-format, men fortællingerne er først og fremmest skrevet til $\varnothing$ ret.

\section{At skrive til lyd: Håndværksmæssige udfordringer}

Hvad er så det særlige ved at skrive en fortælling, som er beregnet til at blive lyttet til? På en måde måske slet ingenting: Nærlæser man toplisten hos Storytel, er de fleste titler 'almindelige' bøger i indlæst form, det vil sige titler, som også sælges over disken hos boghandleren. Streamingtjenestens brugere lytter altså gerne til 'normale' udgivelser skrevet til det trykte bogformat. Samtidig er dette også at forenkle sagen, eftersom flere af de forlag, hvis titler ofte ses på Storytels topliste, er begyndt at betragte deres udgivelser først og fremmest som lydbøger og kun sekundært som trykte bøger. Derfor virker det naturligt, at de i større udstrækning forsøger at få deres forfattere til at skabe fortællinger, som passer til lydbogsbrug, også selvom disse forfattere ikke, som jeg, skriver for et format, som specifikt er skabt af en lydbogstjeneste.

I indledningen nævnte jeg, at de udfordringer, som en lydbogsforfatter stilles over for, kan deles op i to dele, hvor de håndværksmæssige udfordringer udgør den ene del og manglen på litterær anseelse den anden (hvor sidstnævnte også påvirkes af manglen på et fysisk produkt). Lad mig begynde med håndværket: Ud fra de erfaringer, jeg har fået i de år, jeg har arbejdet med lyd som primær platform, er jeg kommet frem til, at der findes fire praktiske udfordringer, som forfattere må forholde sig til, hvis de vil skrive tekster, der fungerer godt i lydbogsformatet. Jeg vil gå igennem dem én for én, men oplister dem indledningsvist her:

1) Lyttere er mindre loyale end læsere af trykte bøger

2) Lyttere er mindre koncentrerede end læsere

3) Lyttere er nødt til at håndtere teknik

4) Lytteren overlader, til dels, fortolkningen til oplæseren

Lytternes manglende loyalitet mod de enkelte tekster har at gøre med streamingtjenesternes salgsmodel og udbud. Månedsabonnenter med fri adgang til en døgnåben buffet af lydbøger vil som oftest være mindre loyale mod den enkelte tekst, idet de når som helst kan afbryde lytningen eller vælge at lytte til noget andet. I den fysiske verden betaler læseren for en bog i en boghandel eller begiver sig til biblioteket for at låne en bestemt titel. Ganske vist har de fleste af os sikkert et antal bøger i bogreolen, som vi har betalt for og ikke siden har fået læst, eller måske kun er begyndt at læse, men når vi først har investeret penge eller tid i en bestemt bog, er vi mere tilbøjelige til at tilgive forfatteren en langsom begyndelse eller en besværlig passage midt i bogen. Med et månedsabonnement med fri tilgængelighed tilgiver vi imidlertid mindre og klikker uden samvittighedskvaler hurtigt videre til næste titel i vores lytteliste, eller vi forsøger os måske med den dér lokkende bog, som vi lige har 
læst om i avisen eller set et indslag om på morgen-tv. Samtidig er denne model også en fordel for forfatterne, da abonnenter som udgangspunkt risikerer meget lidt, når de giver ukendte værker en chance - det koster intet ekstra. Det har medført, at flere forfattere, som ikke har fået større opmærksomhed på det traditionelle bogmarked, har fået stor fremgang på lydbogstjenesterne. Mikael Ressem, Susan Casserfelt, Lotta Lundh, Samuel Karlsson og Lotta Luxenburg er eksempler på temmelig ukendte svenske spændingsforfattere, som alle været placeret på førstepladsen på Storytels topliste i løbet af de sidste to år. ${ }^{2}$

På trods af de muligheder for opdagelse og succes uden om den etablerede litteraturverden, der således også ligger i formatet, må man dog som forfatter være bevidst om, at publikum generelt har mindre tålmodighed med lydbogen. Det hænger også sammen med det andet punkt på min liste: lytterne er ofte mindre koncentrerede end læsere af trykte bøger. Min egen vej til lydbogslytning kan her tjene som eksempel. Jeg begyndte at lytte for alvor i 2010, da jeg var på barselsorlov første gang; jeg anskaffede mig et par trådløse høretelefoner, som altid sad i ørerne - det antal kilometer, jeg gik tur med barnevognen med en bog i ørerne, kan antageligt måles i tusindtal, og det blev en vane, jeg stadig holder ved lige. I dag har jeg næsten altid høretelefonerne i ørerne, når jeg vasker op, ordner vasketøj, løber, går eller skovler sne (jeg bor i det nordligste Sverige). I mange af disse situationer er jeg langt fra 100 procent koncentreret om det, jeg lytter til.

Da jeg selv er forfatter, forestiller jeg mig, at jeg er mere tilbøjelig end gennemsnittet til at tilgive andre forfattere, når de fortaber sig i unødvendigheder. Hvis min koncentration har været lav, og jeg pludselig indser, at jeg har misset noget vigtigt i fortællingen, anstrenger jeg mig for at spole tilbage det antal minutter, som kræves for at give historien en ny chance. Desværre ved jeg, at langtfra alle lyttere gør sig de samme anstrengelser. Når jeg skriver, er jeg derfor ekstra bevidst om at fastholde læserens opmærksomhed og tilfredshed hele tiden. Når Storytel Originals-satsningen skal forklares med en enkelt sætning, anvendes ofte begrebet "fremadrettet fortælling"; det vil sige, at handlingen hele tiden skal bevæge sig fremad, være fængende og give plads til stærke følelser. Min redaktør i forbindelse med Virus udtrykte det ved vores første samtale sådan her: "Hvis du sidder og skriver og føler at nej, sådan her kan jeg ikke gøre, det bliver for meget, for opskruet - så er det perfekt! Tag altid et - helst to! - skridt længere end du er tilpas ved."

Hvad kan få lytteren til at miste koncentrationen? Unødvendige digressioner, sidespor og miljøbeskrivelser nævnes ofte. Men, og dette understreger jeg, læg vel mærke til ordet unødvendige, for selvfølgelig er miljøbeskrivelser, baggrundhistorier for en hovedperson eller andre typer af sidespor ikke forbudt. Efter min mening bør alle forfattere i redigeringsfasen spørge sig selv, hvad der er relevant: Fører dette fortællingen fremad? Forvirrer den her udvikling mere, end den klargør? Er det relevant, hvordan denne bifigur ser ud? Når man skriver litteratur, der er målrettet lydformatet, skal man måske stille sådanne spørgsmål endnu oftere end ellers.

Det tredje punkt handler om teknik. Som læsere af trykte tekster bliver vi med tiden velbevandrede i læseteknik, uden at vi overhovedet er bevidste om det. Visse af de ting, som vi automatisk udfører ved læsning med øjnene, er svære at kopiere, når vi i stedet lytter til en tekst. Hvordan skimmer man for eksempel dele af en lydbog? 
I en papirbog er det intet problem; vores øjne og hjerne har lært sig at 'skimme', og vi sagtner automatisk farten igen, når vi kommer til det, vi skal fokusere på. På samme måde hvis vi tilfældigvis er kommet til at tænke på noget andet, mens vi har læst, og det går op for os, at vi har misset noget i teksten - vi flytter bare blikket op på siden eller bladrer tilbage for at gå tilbage til det, vi har misset. Hvordan gør vi alt dette, når vi lytter? Det kan lade sig gøre at ændre hastigheden på oplæsningen, men det kræver en del klikken rundt i menuer (og desuden gælder der forskellige fremgangsmåder i de forskellige lydbogsapps), og sidenhen skal indstillingen stilles tilbage, når vi vil lytte i standardhastighed igen. Det bliver besværligt og teknisk. At skiftevis hoppe frem og tilbage i fortællingen i 15-sekunders-intervaller er lettere, men så hører vi slet ikke, hvad der sker i løbet af de sekunder, vi ‘skipper’ - tænk hvis den afgørende ledetråd i den krimi, vi lytter til, findes netop der?

Når jeg skriver mine lydbogsserier, forsøger jeg af disse grunde altid at være tydelig og holde lytteren i hånden ved hele tiden at sikre mig, at det er let at forstå, hvor og hvornår vi befinder os i fortællingen, og hvem det er, som befinder sig der. I en serie som Virus har jeg for eksempel som regel to eller tre parallelle handlingsforløb i gang samtidigt, hvor mine hovedpersoner befinder sig på forskellige steder, enten sammen med nogle af de andre karakterer eller alene. Ved kapitelskift forsøger jeg så hurtigt som muligt at genetablere stedet og minde lytteren om, hvem der befinder sig der, og hvorfor de gør det. Hvis lytteren i modsat fald ved begyndelsen til hvert nyt kapitel skal tænke efter: Vent nu, hvem er det, som sidder i den der bil, hvorfor er de så stressede, og hvad skete der egentlig sidste gang, de var med? - så er der stor risiko for, at man skaber irritation.

En anden forskel mellem læsning og lytning er, at det altid er let at holde pause fra læsningen af en trykt tekst - vi løfter bare blikket fra bogsiden - men med en lydbog kræves en håndbevægelse, som i visse situationer kan være besværlig. Hvis man for eksempel har startet en lydbog på mobilen med højtalerfunktionen slået til og derefter har lagt telefonen lidt væk og taget et par opvaskehandsker på og er begyndt at vaske op, hvordan skal man da hurtigt stoppe mobilen for at tænke efter, hvis behovet opstår for det? Med indsæbede, handskebeklædte hænder er det ikke helt let (jeg skal indrømme, at jeg af og til har ladet min næsetip fungere som finger). I stedet for at sætte telefonen på pause begynder man sandsynligvis at tænke efter samtidig med, at fortællingen ruller videre i baggrunden, hvilket på sin side yderligere er med til at forøge ens irritation, eftersom man så risikerer at misse det, som sker i fortællingen i dette nu. Så er det bedre at undgå denne situation ved i første omgang at lave tydelige introduktioner og forbindelseslinjer til tidligere handlingsspor ved hvert nyt kapitel samt gennemgående anvende en kontinuerligt fremadrettet fortællestil og et afgrænset antal hovedpersoner, som er lette at skelne fra hinanden.

Så er der tidsdimensionen - hvordan håndterer vi spring i tid, når vi lytter? I tvverdenen, som lydbogsserierne har lånt deres form fra, tyer man ofte til greb som tidstypisk tøj og frisurer, og måske laver man endog en såkaldt 'fade-in', hvor farvetonen ændres, sommetider til sort-hvid, men lige så ofte til en forstærket farveskala med et blødt filter som for at signalere en uskyldigere fortid. Disse greb har vi lært betydningen af, eftersom vi har set dem siden barnsben. Eller man kan anvende specifikke greb, som i tv-serien Lost, hvor seerne hurtigt lærte sig, at en forflyttelse 
i tid og rum var på vej, hver gang en suggestiv swooshende lyd blev anvendt ved et sceneskift. Hvordan gør man det i en lydbog? Lægger vinyl-skratten på, eller låner swoosh-lyden? Måske, men det har vist sig, at mange lydbogslyttere ikke bryder sig om lydeffekter og musik-indslag i lydbøgerne. De vil have deres lytteoplevelse 'ren'. Jeg forsøger derfor i stedet at være tydelig og gøre min fortælling enkel uden for den sags skyld at simplificere den.

Jeg forsøger også at undgå selv at blive teknisk. Det er ikke usædvanligt, frem for alt inden for kriminalprosa, at hovedteksten bliver afbrudt af for eksempel udskrevne politi-forhør, promemorier eller andre typer af dokumenter for at skabe en oplevelse af autenticitet. James Ellroy er en af de forfattere, som ofte benytter sig af dette, og svenske Jens Lapidus har hentet inspiration fra Ellroy - således findes der flere ligheder mellem Ellroys American Tabloid og Lapidus' Snabbe cash, som begge indeholder flere eksempler på dette greb. I de seneste år har udskrifter af email og sms-samtaler også fundet vej ind i litteraturen. På papir kan det have en god effekt, men når sådanne materialer bliver læst op i en lydbog, opstår der i mine ører en distance mellem den oplæste tekst og lytteren, og effekten bliver faktisk det modsatte af autentisk.

Det fjerde jeg forsøger at have i baghovedet, når jeg skriver, er, at jeg overlader fortolkningen til en skuespiller. Selvfølgelig kan læsere af trykte tekster også frit skabe deres egne billeder og stemmer i hovedet, men i en lydbog bliver det mere definitivt; som lytter er det svært at se bort fra de dialekter og betoninger, som en oplæser giver fortællingen. Her findes der en del faldgruber. Bevidste gentagelser, som anvendes som et stilistisk greb for at skabe en effekt, kan for eksempel falde til jorden, hvis skuespilleren ikke forstår, hvordan forfatteren har tænkt sig, at disse skal betones. Tidligere i denne tekst anvendte jeg for eksempel frasen: "hvor vi befinder os i fortællingen, og hvem som befinder sig der." Uden betoning på de kursiverede ord kommer sådan en sætning til at fremstå klodset, og oplæsningen skærer i lytterens ører. Overordnet bliver gentagelser tydeligere ved oplæsninger end ved traditionel stillelæsning. Mange indlæsere kan håndtere dette, men man kan ikke som forfatter forudsætte, at dette er tilfældet. Er man desuden tæt på deadline, og har den indlæsende skuespiller måske stået på en teaterscene til sent aftenen inden og er tidligt i lydstudiet morgenen efter og i øvrigt booket ind til et dobbeltpas for at undgå, at bogen bliver forsinket - ja så er skuespilleren sandsynligvis udmattet henad eftermiddagen og har ikke forstået, hvor 'genialt' forfatteren har tænkt sig, at netop den sætning skal betones, når der læses op. Jeg er derfor begyndt at forsøge at vejlede indlæseren gennem kursiveringer for at markere, hvor det er ekstra vigtigt, at der lægges et vist tryk på ordene. Det gør jeg, efter at jeg selv har oplevet, at sætninger, som jeg har været meget tilfreds med, da jeg skrev dem, har lydt helt intetsigende, eftersom skuespilleren ikke har forstået, hvordan jeg havde tænkt mig det hele.

Indlæseren bliver også vigtig, når det gælder dialoger og replikker. På en trykt bogside ser man konkret, hvordan der veksles mellem to eller flere personer i en dialog. I en lydbog, hvor du kun har øret at forlade dig på, er det ikke lige så let at afgøre, hvem det er, der taler. En god indlæser kan med relativt små ændringer i stemmen tydeliggøre, hvem der taler, men det er stadig vigtigt, at forfatteren er 
tydelig - ikke mindst for at læseren skal kunne følge med. Det gøres dels ved at skabe karakterer, som er lette at skelne fra hinanden, dels gennem konkrete tekstmarkører. Her kommer vi ind på gentagelserne igen. I en trykt bog forstyrrer det os ikke så meget, hvis hvert dialogskifte afsluttes med, for eksempel, "siger Lisa", "siger Anders", "siger Tora" gang på gang - hjernen sorterer det helt enkelt bare fra - men det bliver hurtigt trættende, når en indlæser læser disse markører højt gang på gang. Eftersom lydbøger gerne er dialogtætte - samtale gør sig godt på lyd - er det vigtigt, at man forsøger at skabe en lethed i dialogerne. Jeg forsøger derfor dels at variere "siger"-ordene, dels lede lytteren på rette vej på anden vis.

En anden type gentagelse, jeg forsøger at undgå, er, når følelser beskrives, efter at de allerede er blevet dramatiseret af indlæseren. Tag følgende enkle eksempel, hvor en lærer er utålmodig med sine støjende elever: "Men skal det være så forbasket svært - sid ned og fokusér på opgaven', råber Lars vredt; hans ansigt lyser rødt af frustration." Når vi læser dette stille med øjnene, er der ikke noget mærkeligt ved det. Men i en lydbog indlæst af en erfaren skuespiller, er udbruddet allerede blevet dramatiseret i citatet, når fortsættelsen, "råber Lars vredt" kommer. Informationen, som har en funktion i den trykte tekst, bliver overflødig i lydbogen. Så er det bedre allerede fra begyndelsen at skrive omtrent sådan her: "Til sidst taber Lars tålmodigheden. Med højrødt ansigt knalder han hånden i katederet. 'Men skal det være så forbasket svært - sid ned og fokusér på opgaven!'” Informationen om lærerens sindstilstand gives her inden selve citatet og er desuden mere dramatiseret end det rent beskrivende "råber Lars vredt" i det første eksempel.

Det kan blive endnu mere mærkeligt, når forfattere beskriver, hvordan nogen taler på skrift, efter at det allerede er blevet dramatiseret af oplæseren. I Stephen Kings seneste roman The Institute dukker en mand op til sidst i fortællingen, som læsper på en meget speciel måde. I den svenske lydbogsversion, Instituttet, dramatiserer skuespilleren Jonas Malmsjö denne læspen på autentisk vis blot for i næste sætning at beskrive, henholdsvis hvilke s-lyde han lige har læspet på, og hvilke han ikke har læspet på. Dette sker ikke blot én gang, men flere, hvilket giver en nærmest komisk effekt, som med al sikkerhed ikke var Kings hensigt. Men eftersom grundreglen for en indlæser er, at de læser præcist det op, som står i teksten, er det ikke usædvanligt, at sådanne situationer opstår.

Opsummerende vil det at skrive til øret således i mange tilfælde sige at skærpe sine markører og være tydelig i forhold til, hvem der taler, hvor og hvornår karakterne befinder sig, ligesom man også må have in mente, hvor læseren befinder sig - og hvornår han eller hun møder informationen i teksten. Man må være opmærksom på de konkrete gentagelser og andre sproglige komplikationer, der opstår, når teksten læses op, samtidig med, at man må fastholde en lytter, som oftest har andre betingelser for at tilgå teksten end læseren af den trykte bog.

\section{Lydbogen i den litterære kultur}

Hvis vi nu lægger den håndværksmæssige del til side, står vi tilbage med den anden del af det, som adskiller lydbogsmarkedet fra det trykte bogmarked: nemlig forskellen på formaternes kulturelle status og de praktiske følger, som dette får. 
Lidt generaliserende vil jeg hævde, at lydbogen og den form for litteratur, som først og fremmest bliver populær på lydbogstjenester, har en meget lav status i den litterære kultur. Forfatteren og litteraturkritikeren Aase Berg opsummerede den generelle holdning til lydbøger ganske godt, da hun i Dagens Nyheter i april 2018 beskrev lydbøger som "børnelitteratur for voksne" - en kategorisering, som i øvrigt ikke bare indebærer en nedvurdering af lydbogen, men også børnebogen som underforstået 'dårlig' eller lavstatus-litteratur. Skiftet fra læsning af trykte bøger til lytning ses således som et led i en pågående fordummelse af det kulturelle klima. Til trods for at lydbogen ofte fremstilles som en trussel i den diskussion, som nu og da er blusset op på svenske kultursider i de seneste år, fremstår nøglepersoner inden for den litterære sfære oftest uinteresserede i at udforske formatet. I Dagens Nyheter - hvor store dele af diskussionen om lydbøger har været ført i Sverige - skrev for eksempel litteraturkritikeren Jonas Thente i marts 2018, at for ham var lydbøger "et lige så ligegyldigt fænomen som duftmusik eller smagsskulpturer" (Thente 2018).

Selv har jeg aldrig rigtigt regnet mig som tilhørende den litterære sfære. Derimod har jeg relativt ofte haft min gang inden for de højlitterære miljøer i løbet de 15 år, hvor jeg har været virksom som forfatter og kulturskribent. I takt med, at lydbøgerne har vokset sig stærkere, er følgende scene begyndt at udspille sig igen og igen: Jeg befinder mig ved en litteratur-sammenkomst, og nogen stiller det sædvanlige spørgsmål: "Hvad skriver du på lige nu?” Jeg svarer, at jeg skriver en lydbogsserie for Storytel Originals. Nu bliver blikket i spørgerens øjne glasagtigt, og interessen falmer og forsvinder snart helt. Ligegyldighed, som sagt; lydbøger er for personen, jeg taler med, ikke litteratur. Tiden går, og personen kontakter mig via Facebook Messenger - det er nu kommet vedkommende for $\varnothing r e$, at det her med at tilpasse sine tekster til lydbogsmarkedet er begyndt at blive efterspurgt. Vil jeg, som arbejder med det, kunne sende nogle af de bøger over, som jeg har skrevet for Storytel? I pdfformat altså? For at lytte selv har de ingen interesse i.

Men, kan man så spørge, gør det noget, at den litteratur, som skrives primært til lydbogsmarkedet, har en lav kulturel status? Storytel passerede grænsen for en million abonnenter i 2019, og min lydbogsserie Virus findes oversat til over ti af Storytels internationale markeder (desværre ikke det danske). De ældre sæsoner af serien finder hele tiden nye lyttere, når en ny sæson er aktuel: åbenbart findes der en stor målgruppe, som kan lide det, jeg skriver, så bortset fra at det for mig personligt er en lille torn i øjet, hvilken rolle spiller det så, at det litterære parnas behandler formatet, jeg skriver for, som den rene luft?

Det gør noget, fordi det får konsekvenser i næste led, for til trods for, at bogbranchen som helhed hele tiden bliver mere digital, er det fortsat i stor udstrækning bogen som fysisk produkt, som får opmærksomhed. Kulturredaktioner har endnu ikke lært, hvordan de skal håndtere et litterært produkt, som først og fremmest eksisterer på digitale platforme. Det er stadig først, når en fysisk bog leveres til en kulturredaktørs skrivebord, at den redaktionelle proces går i gang, som resulterer i en anmeldelse eller et forfatterinterview. Og hvis man ikke er med fra begyndelsen, er det så godt som umuligt at passere mållinjen.

Ganske vist har de daglige avisers kultursider i løbet af 2010'erne mistet deres betydning for, hvad det er for en litteratur, som når ud til læserne. Samme proces 
med fokus på det fysiske produkt præger imidlertid de nye platforme, som delvist har erstattet kultursiderne. I slutningen af 00'erne begyndte bogbloggerne at få stadig større betydning i Sverige, og i løbet af det seneste årti er disse blogs blevet suppleret med populære "bogtippere", særligt på Instagram. Selv her er det slående, hvor ofte de tips, som lægges ud med hashtagget \#bookstagram har fokus på fysiske bøger, som bloggerne har fået tilsendt fra forlag. I takt med, at Instagram er vokset frem og i mange tilfælde har erstattet bogbloggerne, er de fysiske eksemplarer faktisk blevet vigtigere, eftersom Instagram først og fremmest er et billedmedium, og fysiske bøger gør sig godt på billeder. Man kan selvfølgelig lige så godt lægge et billede ud af et digitalt omslag, men så forsvinder følelsen af eksklusivitet: ved at vise et fysisk produkt frem signalerer bookstagrammeren, at vedkommende er udvalgt: forlaget har valgt at bruge reelle ressourcer på at sende en bog ud per brev til netop dem.

Her går det op ad bakke for de heldigitale aktører. Hos Storytel Originals fandtes der i begyndelsen ingen plan for at imødegå disse tendenser, og i skrivende stund har de stadig lang vej at gå. I efteråret 2019 lancerede de dog en platform for anmeldelser af lydbøger gennem tjenesten Clipsource, som mange virksomheder inden for tv-streaming også benytter sig af. Hvorvidt satsningen har båret frugt, er for tidligt at sige, men jeg vil vove at påstå, at de fleste kulturredaktioner, bogbloggere og bookstagrammere foretrækker at få en bogpakke leveret til deres brevsprække frem for en email, hvor man via et link får adgang til at lytte til en mp3-fil (som dertil kun kan streames i en webreader og ikke downloades og lyttes til uden internetopkobling).

Fraværet af en fysisk bog, som kan vises frem, udelukker også den digitale forfatter fra vigtige udstillingsvinduer som for eksempel boghandleren og biblioteket. Boghandleren er efterhånden mere blevet til et showroom for litteratur end et sted, hvor man køber bøger - man besøger butikken for at få tips, læser nyhedsbreve, som kommer fra netboghandlerne, for at få inspiration, og ser, hvilke titler de markedsfører i reklamesammenhæng. I stedet for at købe de bøger, som boghandleren fremhævede, går vi efterfølgende ind i vores lydbogsapp og lytter til dem. Men som sagt - hvis ikke den omtalte bog kan besigtiges i et udstillingsvindue, finder ingen ud af, at den findes. Ligeledes udelukkes en lydbogsforfatter fra muligheden for at blive booket til signeringer hos boghandleren eller til forfattersamtaler på biblioteket, eftersom selv disse aktiviteter er forbundet med, at man efterfølgende skal kunne købe eller låne en bog af den indbudte forfatter.

Det samme gælder i stor udstrækning bogmesser og litteraturfestivaler, som i reglen lever i symbiose med de værker, som bliver løftet frem i andre sammenhænge. Dertil bør man ikke undervurdere symbolværdien i, at en moderator, som styrer en scene-samtale, skal kunne løfte den bog op, som de nu taler om, og vise den frem til publikum. Er man hovedsagligt tilgængelig på digitale platforme, kommer man oftest udelukkende på tale som medvirkende, hvis der findes et særligt programpunkt som handler om digitaliseringen eller lydbogens fremvækst.

At bogen som fysisk objekt fortsat har en reel værdi, adskiller den fra andre kunstformer, som har gennemgået en digitaliseringsproces. Inden for film- og tvverdenen har skuespillere og regissører aldrig på samme vis været afhængige af, at publikum skal kunne eje de produkter, som markedsføres: at samle film på VHS, 
DVD og Blu-ray blev snarere en parentes i filmmediets historie. Inden for musikverdenen har der længe været samlere, og ganske vist har kunstnere langt tilbage i tiden signeret LP'er eller CD’er, men der har også været en rodfæstet tradition for, at fans i forbindelse med koncerter og lignende køber andre former for såkaldt merchandise - som trøjer, plakater, krus og tørklæder med kunstnerens navn på. Inden for bogverdenen er dette aldrig slået igennem, eftersom bogen som artefakt i sig selv har været så perfekt et produkt og desuden har fastholdt sin form gennem flere århundreder.

Jeg tror, at dette er en vigtig årsag til, at den fysiske bog som produkt hidtil har vist sig at kunne modstå digitaliseringen på mere livskraftig vis end modsvarende produkter inden for film, tv og musik. For den almindelige bruger spiller det helt grundlæggende ingen rolle, hvorvidt en film, vi ser på fjernsynet, kommer til os fra en Blu-ray-skive eller via en streamingtjeneste som Netflix; det, vi ser på skærmen, er nærmest fuldstændig det samme. Ligeledes påvirker det ikke vores oplevelse nævneværdigt, om musikken, som flyder ud af vores højtalere, kommer fra en CD eller et Spotify-abonnement; for normal-øret lyder det ens. Bogen er anderledes. Selvom vi kan synes, at det går fint at læse en e-bog, vil ingen lydbogslyttere i en blindtest forveksle det, de gør, med at læse en fysisk papirbog: forskellen i selve læseoplevelsen er helt enkelt for stor.

Taler vi specifikt om lydbøger, bliver situationen en anden og følger mere samme udvikling, som vi har set inden for film-, tv- og musikverdenen. Helt konkret er lydbogsformatet gammelt, og lydbøger lyder i dag nogenlunde, som dengang de eksisterede i form af kassettebånd eller CD’er, men måden, vi bruger dem på, og ikke mindst tilgængeligheden har taget gigantiske skridt i forbindelse med smartphoneog app-revolutionen. Digitaliseringen har forbedret brugeroplevelsen og bidraget til formatets kraftige vækst.

Men tilbage til de digitale forfatteres udfordringer med at nå ud til det bredere marked: Et yderligere dilemma for forfattere, som skriver for Storytel Originals, er, at de udelukkende figurerer på en begrænset del af et i forvejen begrænset marked. Storytel er ledende blandt de svenske streamingtjenester for lydbøger med cirka 70 procent af markedet, men det er stadig en platform, som tillader os at nå ud til betydeligt færre læsere sammenlignet med de forfattere, som udgives på det åbne bogmarked. På hvilken måde dette faktum yderligere mindsker kulturredaktørernes opmærksomhed over for Storytel Originals-udgivelser er svært at afgøre, men vi kan i hvert fald slå fast, at det nok ikke forstærker den. Alt dette medfører, at vi, som skriver for Storytel Originals, i højere grad end 'almindelige' forfattere er afhængige af eksponering via Storytels egne kanaler - dels i selve lydbogsappen, dels i virksomhedens sociale medie-flow - for at nå ud til vores lyttere. Dette indebærer en balancegang for Storytel, som dels må agere som et forlag, der vil gøre reklame for sine egne titler, dels som en neutral platform for andre forlags udgivelser; forlag som på deres side har fokus på, hvilken eksponering deres egne og andres bøger får. En lignende situation findes i øvrigt hos Storytels konkurrent Bookbeat, som ejes af Bonnierkoncernen, der på sin side også ejer Sveriges største og mest toneangivende forlagskoncern. Bookbeat har ikke (i det mindste ikke endnu) nogen Originallignende udgivelser, men må forsøge at afbalancere sin egen koncerns udgivelser i forhold til den øvrige forlagsverdens. 
Lykkes denne balancegang for Storytel? Jeg taler selvfølgelig for mig selv her, men mit svar bliver nja; jeg vil mene, at de, for at undgå kritik fra andre forlag, undereksponerer egne udgivelser. Min indstilling er, at i og med at de har besluttet sig for at have en egen forlagsudgivelse, bør de også kunne løfte denne frem - eftersom ingen andre aktører $g ø r$ det. Sammenlignet med bøger fra traditionelle forlag, som får opmærksomhed i dagspressen, på sociale medier og fysiske boghandlere såvel som hos netaktører som Adlibris, har Storytel Originals-udgivelserne (og andre rent digitale udgivelser) store udfordringer at kæmpe med.

Jeg er ikke alene om at gøre opmærksom på dette. I et indlæg fra december 2019 i den Storytel-administrerede svenske Facebook-gruppe "Snacka om ljudböcker", som med sine knap 17000 medlemmer er det største Facebook-forum for lydbøger i Sverige, stillede forfatteren Johan Rosenlind samme spørgsmål. Rosenlind er tidligere først og fremmest kendt som manuskriptforfatter og er en af hjernerne bag SVTs dramasucces Vår tid är nu, men debuterede i efteråret 2019 som skønlitterær krimiforfatter sammen med Lotta Fritzdorf med Ticktick boom på digitalforlaget Bonnier Bookery. Rosenlind skrev blandt andet, at han har noteret, at "historier, som er skrevet direkte til lyd, går glip af anmeldelser og ikke bliver nominerede til forskellige krimi/thriller-priser etc.", og han fortsatte med at konstatere, at branchen synes at tage udgangspunkt i papirbøger trods den enorme øgning af lydb $\varnothing$ ger på markedet. I den diskussion, som herefter opstod, blandt andet med mig, skrev han endvidere, at han havde været $\mathrm{i}$ kontakt med en del anmeldere og diskuteret spørgsmålet og syntes at have fået bekræftet, at problematikken eksisterer; de heldigitale udgivelser er i dag ikke med i udvalgsprocessen, når det handler om at vælge bøger ud til anmeldelse mv. Dette faktum bliver ekstra interessant, når man tænker på, at "lydbogificeringen" i sig selv har fået meget medie-opmærksomhed. Siden sommeren 2016, da Storytel Originals-konceptet blev lanceret i Sverige og kom til at blive et symbol for denne udvikling af branchen, er der blevet skrevet et meget stort antal artikler om lydbogens fremgang i svenske kultur- og erhvervsmedier, ofte med fokus på netop Storytels succeshistorie. Men lydbogen behandles i disse tekster fortsat - snart fire år senere - oftest som fænomen eller som trussel samtidig med, at lydbogslitteraturen i sig selv aldrig er blevet udsat for nogen kritisk undersøgelse.

Her kan jeg selv udgøre et eksempel. Allerede inden jeg blev en del af Storytel Originals-konceptet, deltog jeg nu og da i mediedebatten omkring digitaliseringen af bogbranchen, da det er et spørgsmål, som jeg længe har fundet interessant og gerne diskuteret. Når jeg dertil er blevet den Storytel Originals-forfatter, som har været allermest produktiv, har jeg ofte været én af dem, som er blevet bedt om at udtale mig om de reportager, som bliver skrevet om emnet. I de seneste år har jeg derfor figureret i tekster og indslag om lydbogsudviklingen hos blandt andet Dagens Nyheter, Svenska Dagbladet, nyhedsbureauet TT, Sveriges Television, Sveriges Radio, Göteborgs-Posten, Sydsvenskan, branchetidsskrifterne Svensk Bokhandel og Boktugg samt i kulturtidsskrifter som Tidningen Vi, Skriva og finlandssvenske Ny Tid. Jeg har også på det seneste været engageret som forelæser om lydbogsudviklingen samt fra efteråret 2019 som underviser i at skrive til lydbogsformatet inden for rammerne af Folkeuniversitetets kursusvirksomhed i Stockholm. 
I betragtning af den enorme interesse for lydbogen, når det gælder, hvordan den påvirker bogbranchen, er det slående, hvor lav interessen samtidig har været for at forholde sig kritisk til de værker, som står i centrum for debatten. Til dags dato er cirka 65 Storytel Originals-serier for voksne blevet udgivet i Sverige, og af disse er cirka ti blevet fortsat i en eller flere sæsoner, hvilket i skrivende stund giver i alt 90 Originals-sæsoner i Sverige. Der gik 14 måneder, før nogen af disse Originalfortællinger blev anmeldt i et dagblad, men i august 2017 anmeldte lokaltidsskriftet i Gävle første sæson af min lydbogsserie Virus. Dog bør det nævnes, at denne allerede blev udgivet i lydbogsform i sommeren 2016, og at det ikke var lydbogen, som var genstand for anmeldelsen, men derimod pocket-udgaven af første sæson, som netop var udkommet i august 2017. Derefter gik der yderligere knapt et år, før nogen Storytel Originals-produktion fik opmærksomhed på kultursiderne. Denne gang var det faktisk selve lydbogen, som var i centrum, i form af Martina Montelius' serie Stackars Birger, som blev anmeldt i eftermiddagsbladet Expressen i slutningen af september 2018 og i morgenavisen Svenska Dagbladet et par uger senere. Her bør dog nævnes, at omstændighederne omkring Stackars Birger på flere måder var specielle: Martina Montelius er en kendt kulturpersonlighed i Sverige, og hun var en af de 18 kvinder, som i november 2017 i efterdønningerne af Me Too-bevægelsen vidnede om seksuelle overgreb og chikane i Dagens Nyheters store unders $\varnothing$ gelse af den såkaldte Kulturprofil og dennes forbindelse til det Svenske Akademi. ${ }^{3}$ Montelius er dertil datter af akademi-medlemmet Kristina Lugn, hvilket yderligere gav hendes historie et skub i retning af mediernes rampelys. Stackars Birger, som Martina Montelius selv var indlæser på, er en satirisk refleksion over kulturmandens opførsel i teaterverdenens Stockholm i skyggen af Me Too, et emne som ved udgivelsen fortsat var brandvarmt, eftersom retssagen mod kulturprofilen stadig pågik i Stockholm. At Stackars Birger trods dette kun blev anmeldt af to aviser siger en del om indstillingen til lydbogsformatet. Det er ikke en dristig påstand, at hendes fortælling ville have fået betydeligt flere anmeldelser, hvis den fra begyndelsen var blevet publiceret som en trykt roman (den er sidenhen blevet udgivet i pocketformat).

Det er selvfølgelig ingen ret for en forfatter at blive anmeldt i forbindelse med en bogudgivelse, uanset hvilken form udgivelsen har. Flertallet af Storytel Originalsserierne er dertil det, man kalder underholdningslitteratur, som heller ikke i traditionelle udgivelsesformater plejer at få kulturredaktionernes opmærksomhed i større grad (selvom det er blevet mere almindeligt i de seneste år). Men alligevel -i lyset af den store opmærksomhed, som Storytel Originals-konceptet har fået, når det gælder bogbranchens udvikling, er det stadig interessant at konstatere, at ingen i princippet forholder sig til indholdet af disse serier.

Jeg har selv forsøgt at gøre opmærksom på denne problematik. Da lydbogsdebatten var på sit højeste og blev udfoldet i et antal debatindlæg i morgenavisen Dagens Nyheter i foråret 2018, bidrog jeg med en tekst, hvor jeg forsøgte at få landets kulturredaktioner til at behandle lydbogen som mere end bare en trussel. Problemet, som jeg så det, var blandt andet, at debatten i så høj grad handler om, at forlagene alene har satset på bred underholdningslitteratur i lydbogsformatet, hvilket ifølge dem skader mangfoldigheden i bogudgivelserne; et billede som jeg 
ikke fuldt ud var enig i. "Hinsides bestsellerlisterne og de brede titler, som tjenester som Storytel og Bookbeat sætter i forgrunden, findes der et rigt udbud af indlæst litteratur" (Åberg 2018), skrev jeg og fortsatte:

14 Det står ikke så skidt til, som diskussionen giver indtryk af. Hvorfor fremstår det så sådan? Lydbogstjenesterne bærer selv en del af skylden, idet de bevidst markedsfører lydbøger som noget, man kan benytte sig af, samtidig med at man gør noget andet - motionerer, laver mad eller gør rent - hvilket tilgodeser underholdningslitteraturen. Men der findes jo ikke noget, som siger, at vi udelukkende kan lytte samtidig med, at vi vasker op. Det er fantastisk at give sig helt og holdent hen i en indlevelsesfuld indlæsning af en storslået roman - bare ikke lige så let at visualisere i en reklame. Men den tungere, indlæste litteratur rammes også af, at der mangler en fortløbende omtale af litteratur til lytning i medierne. Der skrives ganske vist om lydbøger, men kun når de forvolder turbulens i bogbranchen. (Ibid.)

Jeg fremlagde derefter et konkret forlag: Hvis kultursiderne nu ikke var interesserede $\mathrm{i}$ at begynde med at anmelde lydbøger, så skulle de vel i det mindste kunne begynde med at anerkende formatets eksistens? Anmeldelse af papirbøger bliver altid ledsaget af en lille fakta-boks, som angiver genre, udgivende forlag, eventuelt oversætternavn og antal sider i bogen. Skulle disse fakta-bokse ikke kunne udvides med linjen: "findes også som lydbog, indlæst af XXX"?

Det ville ganske vist ikke ændre noget for mig personligt, eftersom min primære udgivelseskanal er en heldigital platform, men det ville i hvert fald være et lille skridt på vejen mod at løfte lydbogen frem i forhold til hverdagslige litteratur-omtaler, og informationen ville desuden med sikkerhed blive værdsat af såvel avislæsere som forlag. Til dags dato har ingen avis dog vist sig modtagelig over for ideen: Her fire år efter, at jeg begyndte at skrive for Storytel Originals-konceptet, bliver jeg og mine digitale forfatterkolleger fortsat først og fremmest set som en trussel mod tingenes orden.

Oversat fra svensk af Sara Tanderup Linkis

\section{Noter}

I I Danmark markedsføres Storytel Originals under navnet Mofibo Originals, idet de produceres af den danske afdeling af Storytel, Mofibo. Markante danske Originals-forfattere er bl.a. Christian Frost, Lotte Petri og Eva Marie Fredensborg. Se også Iben Have og Mille Jensens artikel om Storytel Originals i dette nummer.

2 For en diskussion af Storytels toplister, se Åberg 2019.

3 Kulturprofilen er de svenske mediers betegnelse for den fransk-svenske kulturpersonlighed Jean-Claude Arnault, som er gift med det tidligere medlem af det Svenske Akademi, Katarina Frostenson, og som i 2017 blev anklaget og siden dømt for en række seksuelle krænkelser. 


\section{Litteratur}

Schmidt, Lars (2016): "Riktigt dåliga avtal", i Svensk Bokhandel, 9. september 2016: https://www. svb.se/nyheter/riktigt-daliga-avtal

Thente, Jonas (2018): “Albert Bonniers förlag vill nog stanna kvar på sitt fundament”, i Dagens Nyheter 27. marts 2018: https://www.dn.se/kultur-noje/jonas-thente-albert-bonniers-forlag-vill-nogstanna-kvar-pa-sitt-fundament/

Åberg, Daniel (2018): “Varför ignorerar kritikerna ljudboken”, i Dagens Nyheter 24. april, 2018: https://www.dn.se/kultur-noje/kulturdebatt/varfor-ignorerar-kritikerna-ljudboken/

Åberg, Daniel (2019): “Storytels topliste - en djupdykning” (blogpost), 2. august 2019: http://www. danielaberg.se/storytels-topplista-en-djupdykning/ 